\title{
Hubungan Pengawas Minum Obat dan Tipe Dukungan Keluarga Terhadap Kepatuhan Minum Obat Pasien Tuberkulosis Paru di Kota Banda Aceh
}

\author{
Zulheri $^{1, *}$, Fadli Syahputra ${ }^{2}$, Lidyawati ${ }^{2}$ \\ ${ }^{1}$ Akademi Keperawatan Teungku Fakinah Banda Aceh, Banda Aceh, Indonesia \\ ${ }^{2}$ Akademi Farmasi YPPM Mandiri, Banda Aceh, Indonesia \\ Email: ${ }^{1}$ zulherii02@gmail.com
}

\begin{abstract}
Abstrak-Kota Banda Aceh merupakan ibu Kota Provinsi Aceh dengan kasus tuberculosis paru mendapatkan peringkat dua terbanyak. $\mathrm{Hal}$ ini dapat dilihat dari peningkatan angka kejadian tuberculosis paru di Kota Banda Aceh. Tujuan penelitian ini untuk mengetahui hubungan peran PMO dan dukungan keluarga dengan kepatuhan minum obat anti tuberculosis paru di wilayah kerja Dinas Kesehatan Kota Banda Aceh. Jenis penelitian ini bersifat deskriptif analitik dengan Desain Cross Sectional dan objek penelitian berjumlah 128 orang penderita TB Paru di Kota Banda Aceh. Penelitian dilakukan selama 3 bulan dari bulan Agustus-November 2018 berlokasi di seluruh Puskesmas wilayah kerja Dinas Kesehatan Kota Banda Aceh analisis data menggunakan uji regresi logistic. Hasil menunjukkan bahwa $82 \%$ patuh minum OAT, $53.9 \%$ mendapatkan pengawasan PMO, $57.8 \%$ mendapatkan dukungan instrumental, $53,1 \%$ mendapatkan dukungan informasi, 56,2\% mendapatkan dukungan penilaian, $64.0 \%$ mendapatkan dukungan emosional, 63.2\% mendapatkan dukungan spritual, 50,7\% mendapatkan dukungan finansial. hasil statistk diperoleh ada hubungan PMO $(O R=$ $18,5 \mathrm{P}$-Value $=0,000)$ ada dukungan informasi $(O R=5.4$, P-value $=0,002)$, ada dukungan emosional $(O R=3.54, \mathrm{P}-\mathrm{Value}=0,027)$, ada dukungan finansial $(O R=0.22$, P-Value $=0,018)$, tidak ada dukungan instrumental $(O R=2.5$, P-Value $=0.050)$, tidak ada dukungan penilaian $(\mathrm{OR}=1.22$, $\mathrm{P}-\mathrm{Value}=0.664)$, tidak ada dukungan spritual $(\mathrm{OR}=0.55, \mathrm{P}-\mathrm{Value}=0,247)$.
\end{abstract}

Kata Kunci: Kepatuhan Minum OBAT; Peran PMO; Dukungan Keluarga; TB Paru

\begin{abstract}
Abstact-Banda Aceh City is the capital of Aceh Province with the highest number of lung tuberculosis cases. This can be seen from the increase in the incidence of pulmonary tuberculosis in Banda Aceh City. The purpose of this study was to determine the relationship between the role of PMO and family support with pulmonary anti tuberculosis (OAT) drugsThis type of research is analytic descriptive with Cross Sectional Design and the object of research is 128 people with pulmonary TB in Banda Aceh City. The study was conducted for 3 months from August-November 2018 located in all Puskesmas working areas of the Banda Aceh City Health Office data analysis using logistic regression tests. Results PMO supervision, 57.8\% received instrumental support, 53.1\% received information support, $56.2 \%$ received valuation support, $64.0 \%$ received emotional support, $63.2 \%$ received spiritual support, $50.7 \%$ received financial support. statistical results obtained there is a PMO relationship $(\mathrm{OR}=18.5 \mathrm{P}-\mathrm{Value}=0,000)$ there is information support $(\mathrm{OR}=5.4$, $\mathrm{P}$-value $=0.002)$, there is emotional support $(\mathrm{OR}=3.54, \mathrm{P}$-Value $=0.027)$, there is support financial $(\mathrm{OR}=0.22, \mathrm{P}-\mathrm{Value}=0.018)$, no instrumental support $(\mathrm{OR}=2.5, \mathrm{P}-$ Value $=0.050)$, no valuation support $(\mathrm{OR}=1.22, \mathrm{P}-\mathrm{Value}=0.664)$, no support spiritual $(\mathrm{OR}=$ 0.55 , P-Value $=0.247$ ).
\end{abstract}

Keywords: Compliance with OAT Drinking; Role of PMO; Family Support; Pulmonary TB

\section{PENDAHULUAN}

Tuberkulosis atau dikenal dengan istilah TB merupakan suatu penyakit menular yang disebabkan oleh basil mycobacterium tuberculosis yang biasanya mempengaruhi organ paru-paru namun dapat juga mempengaruhi organ lain selain paru-paru. Penyakit ini dapat menular melalui udara dari orang yang terinfeksi ke orang lain, salah satunya melalui batuk. Menurut laporan WH0 (2017) pengobatan terhadap penyakit Tuberkulosis telah menghindari 49 juta kematian di seluruh dunia. Di seluruh dunia, penyakit TB merupakan salah satu ancaman kesehatan masyarakat yang utama yang berlomba-lomba dengan penyakit Human Immunodeficiency Virus (HIV) sebagai penyebab kematian akibat penyakit menular (Sulis et al., 2014).

Pengobatan TB membutuhkan waktu lama, terbatasnya informasi mengenai TB dan masih adanya stigma tentang TB di masyarakat, efek samping obat, sehingga ada kemungkinan pasien tidak patuh dalam minum obat. Untuk mengatasi masalah tersebut peran dan dukungan keluarga sebagai pengawas minum obat (PMO) sangat penting dalam hal pendampingan dimasyarakat untuk menurunkan angka putus obat dan meningkatkan kesembuhan serta penemuan kasus TB di wilayahnya (Dinkes, 2017).

Menurut Kemenkes (2017) bahwa keteraturan minum obat merupakan suatu tindakan penderita TB minum obat secara teratur dengan tujuan sembuh dan untuk memutuskan rantai penularan. Keteraturan minum obat dapat dikategorikan apabila tidak pernah lupa minum obat TB selama 14 hari berturut turut pada fase awal yaitu 2 bulan dan 14 hari berturut turut pada fase lanjutan yaitu 4 bulan. Pada kategori tidak teratur minum obat yaitu apabila penderita TB lalai minum obat TB selama 14 hari berturut turut pada fase awal dan fase lanjutan.

Dalam merawat penderita TB paru, peran keluarga sangat dibutuhkan, baik dalam hal perawatan secara fisik maupun perawatan secara psikososial, hal ini disebabkan karena keluarga adalah orang yang paling dekat dengan penderita dan juga sesuai dengan salah satu fungsi keluarga yaitu memberikan perawatan pada anggota keluarga yang sakit (Friedman, 1998).

Penderita TBC sangat membutuhkan kasih sayang, dukungan dan perhatian khususnya keluarga, hal ini dapat diperlihatkan dengan ikut serta dalam membantu perawatan pada penderita TBC. Sehingga dengan adanya kasih sayang, 


\section{Journal of Pharmaceutical and Health Research}

Vol 2, No 3, Oktober 2021, pp. 60-66

ISSN 2721-0715 (media online)

DOI 10.47065/jharma.v2i3.983

dukungan dan perhatian serta perawatan yang baik tersebut akan membantu mempercepat kesembuhan penderita TBC (Pradana, 2018).

Dukungan keluarga juga terkait dengan bidang ekonomi. Tingkat ekonomi merupakan kemampuan finansial untuk memenuhi segala kebutuhan hidup, akan tetapi adakalanya penderita TBC sudah pensiun dan tidak bekerja namun biasanya ada sumber keuangan lain yang bisa digunakan untuk membiayai semua program pengobatan dan perawatan sehingga belum tentu tingkat ekonomi menengah ke bawah akan mengalami ketidakpatuhan dan sebaliknya tingkat ekonomi baik tidak terjadi ketidakpatuhan (Hannan \& Hidayat, 2013).

Berdasarkan laporan hasil survei yang dilakukan oleh WH0 (2017) dari tahun 2014 sampai dengan 2017 di negaranegara di dunia, bahwa penggunaan Directly Observed Treatment Short Course (DOTS) dan strategi stop TB mampu menurunkan beban TB setiap tahunnya. Penggunaan DOTS dan strategi stop TB merupakan pengobatan dengan pengawasan langsung terapi dengan cara membantu pasien mengambil obat secara teratur untuk memastikan kepatuhan pasien dalam pengobatan TB Paru. Kepatuhan pasien dalam pengobatan TB Paru sangat berarti bahwa dunia berada di trek untuk mencapai tujuan Sustainable Development Goals Sustainable (CSDGS) untuk membalikkan penyebaran TB pada tahun 2019 dan angka kematian yang disebabkan oleh TB Paru menurun 45\% dan diperkirakan sekitar 22 juta jiwa di dunia diselamatkan oleh program tersebut (WH0, 2017).

Asia Tenggara dengan 5 dari 22 negara yang memiliki beban TB tertinggi di dunia. Sebanyak 35\% seluruh kasus TB di dunia berada di kawasan ini Kemenkes (2017). Data WH0 (2017) pada tahun 2017 menunjukkan TB paru membunuh 1,5 juta orang di dunia, kematian terjadi pada tahun 2014890.000 laki-laki, 480.000 pada perempuan dan 180.000 pada anak-anak. Terdapat enam negara yang memiliki jumlah kasus baru TB paru terbesar di dunia yakni India sebesar 2.200.000 kasus, Indonesia sebesar 1.000.000 kasus, Cina sebesar 930.000 kasus, Nigeria sebesar 570.000 kasus, Pakistan sebesar 500.000 kasus dan Afrika Selatan sebesar 450.000 kasus.

Prevalensi nasional TB paru berdasarkan data profil Kesehatan indonesia 2017 adalah 156.723 orang dari semua provinsi di Indonesia, tiga provinsi yang mempunyai prevalensi TB paru yang paling tinggi yaitu Provinsi Jawa Barat sebanyak 23.224 orang Provinsi Jawa Timur 21.606 orang dan Provinsi Jawa Tengah sebanyak 14. 139 orang Walaupun diagnosis pasti Tuberkulosis berdasarkan pemeriksaan sputum Basil tahan asam (BTA) positif, diagnosis klinis sangat menunjang untuk diagnosis dini terutama pada penderita TB paru anak, dimana dilaporkan setiap tahunnya diperkirakan ditemukan sebanyak 539.000 kasus baru dengan kematian sekitar 101.000 (Dinkes, 2017).

Provinsi Aceh pada tahun 2017 tercatat jumlah penderita baru dengan Basil Tahan Asam (BTA) (+) sebanyak 7,342 penderita, meningkat bila dibandingkan dengan semua tuberculosis yang ditemukan pada tahun 2016 yang sebesar 5,072 dimana jumlah kasus pada laki-laki lebih tinggi daripada perempuan yaitu 1.8 kali di bandingkan pada perempuan jika kondisi ini terus berlanjut maka Provinsi Aceh akan kehilangan sumber daya manusia yang produktif (Dinkes, 2017).

Berdasarkan data yang diperoleh dari profil Dinas Kesehatan Kota Banda Aceh menunjukan bahwa jumlah penderita tuberculosis paru di tahun 2017 sebanyak 262 kasus.

Kota Banda Aceh merupakan ibu Kota Provinsi Aceh dengan kasus tuberculosis paru peringkat kedua setalah kabupaten Aceh Utara yang mendapatkan peringkat pertama seluruh Provinsi Aceh. Untuk itu perlu adanya upaya meningkatkan program pemberantasan penyakit dari petugas kesehatan maupun masyarakat. Selanjutnya tercapai tujuan bisa menurunnya angka tuberculosis paru, maka perlu adanya peran PMO dan dukungan keluarga untuk bekerja dengan baik. PMO dan dukungan keluarga sangat diperlukan untuk mengontrol dan membantu para penderita tuberculosis paru agar selalu minum obat dan mengontrol secara teratur.

Dari serangkaian observasi pendahuluan dan wawancara pada bulan juli 2018 dengan pasien tuberculosis paru sebanyak 10 responden di wilayah kerja Dinas Kesehatan Kota Banda Aceh dan studi data skunder menunjukkan beberapa kelemahan pada kesembuhan TB paru seperti pasien tidak menjalan program pengobatan TB paru selam enam bulan, terutama minum tidak teratur, jadwal kontrol ulang diabaikan begitu saja serta budaya penderita yang tidak mengerti tentang bahayanya penyakit TB paru yang sangat berisiko menular ke orang lain. Keadaan tersebut akan dipengaruhi kepatuhan minum obat. Oleh karena itu penelitian ini ingin mengkaji adakah hubungan peran PMO dan tipe dukungan keluarga dengan kepatuhan minum Obat Anti Tuberculosis (OAT) paru pada pasien tuberculosis paru di wilayah kerja Dinas Kesehatan Kota Banda Aceh.

\section{METODOLOGI PENELITIAN}

Penelitian ini merupakan penelitian kuantitatif menggunakan jenis desain Cross secsional yaitu variabel dependen dan variabel independen diteliti secara bersama disaat dilakukan penelitian untuk mengetahui peran PMO dan dukungan keluarga dengan kepatuhan minum obat anti tuberculosis Paru (OAT) pada pasien tuberculosis di wilayah kerja Dinas Kesehatan Kota Banda Aceh. Penelitian ini dilakukan pada pasien yang menderita tuberculosis paru di seluruh puskesmas wilayah kerja Dinas Kesehatan Kota Banda Aceh Tahun 2018.

Pengumpulan data diperoleh dengan pengumpulan data primer dan skunder, data primer merupakan sumber data penelitian yang di peroleh secara langsung dari sumber aslinya yang berupa wawancara suatu objek kejadian atau hasil pengkajian.

Analisis data bertujuan untuk mendeskripsikan semua variabel yang disajikan dalam bentuk tabel distribusi frekuensi, analisis data bivariat menggunakan conditional regersi logistic mengunakan prosedur logit program STATA 


\section{Journal of Pharmaceutical and Health Research}

Vol 2, No 3, Oktober 2021, pp. 60-66

ISSN 2721-0715 (media online)

DOI 10.47065/jharma.v2i3.983

13.0, sedangkan analisis multivariat dilakukan dengan tujuan untuk mengambarkan hubungan antara variabel dependent dengan variabel independent secara simultan dalam populasi.

\section{HASIL DAN PEMBAHASAN}

\subsection{Hasil}

Tabel 1. Analisis Univariat

\begin{tabular}{|c|c|c|c|}
\hline No. & Variabel & Frequency & Persentase \\
\hline \multirow[t]{5}{*}{1.} & Umur & & \\
\hline & 10-20 tahun & 5 & $3,9 \%$ \\
\hline & 21-40 tahun & 34 & $26,5 \%$ \\
\hline & 41-60 tahun & 61 & $47,6 \%$ \\
\hline & $>60$ tahun & 28 & $21,8 \%$ \\
\hline \multirow[t]{3}{*}{2.} & Jenis Kelamin & & \\
\hline & Laki-laki & 80 & $62,5 \%$ \\
\hline & Perempuan & 48 & $37,5 \%$ \\
\hline \multirow[t]{6}{*}{3.} & Pekerjaan & & \\
\hline & PNS & 33 & $25,7 \%$ \\
\hline & Wiraswasta & 45 & $35,1 \%$ \\
\hline & Mahasiswa & 16 & $12,5 \%$ \\
\hline & Tidak bekerja & 29 & $22,6 \%$ \\
\hline & Siswa & 5 & $3,9 \%$ \\
\hline \multirow[t]{3}{*}{4.} & Kepatuhan Minum Obat & & \\
\hline & Tidak patuh & 23 & $17,9 \%$ \\
\hline & Patuh & 105 & $82 \%$ \\
\hline \multirow[t]{3}{*}{5.} & Pengawas Minum Obat (I & MO) & \\
\hline & Tidak ada pengawasan & 59 & $46 \%$ \\
\hline & Ada pengawasan & 69 & $53,9 \%$ \\
\hline \multirow[t]{3}{*}{6.} & Dukungan Intrumental & & \\
\hline & Tidak ada dukungan & 54 & $42,1 \%$ \\
\hline & Ada dukungan & 74 & $57,8 \%$ \\
\hline \multirow[t]{3}{*}{7.} & Dukungan Informasi & & \\
\hline & Tidak ada dukungan & 60 & $46,8 \%$ \\
\hline & Ada dukungan & 68 & $53,1 \%$ \\
\hline \multirow[t]{3}{*}{8.} & Dukungan Penilaian & & \\
\hline & Tidak ada dukungan & 56 & $43,7 \%$ \\
\hline & Ada dukungan & 72 & $56,2 \%$ \\
\hline \multirow[t]{3}{*}{9.} & Dukungan Emosional & & \\
\hline & Tidak ada dukungan & 46 & $35,9 \%$ \\
\hline & Ada dukungan & 82 & $64 \%$ \\
\hline \multirow[t]{3}{*}{10.} & Dukungan Spritual & & \\
\hline & Tidak ada dukungan & 47 & $36,7 \%$ \\
\hline & Ada dukungan & 81 & $63,2 \%$ \\
\hline \multirow[t]{3}{*}{11.} & Dukungan Finansial & & \\
\hline & Tidak ada dukungan & 63 & $49,2 \%$ \\
\hline & Ada dukungan & 65 & $50,7 \%$ \\
\hline
\end{tabular}

Tabel 2. Analisis Bivariat

\begin{tabular}{|c|c|c|c|c|c|c|c|c|c|}
\hline \multirow{3}{*}{ No. } & \multirow{3}{*}{ Variabel } & \multicolumn{4}{|c|}{ Kepatuhan Minum Obat } & \multirow{2}{*}{\multicolumn{2}{|c|}{ Total }} & \multirow{3}{*}{ OR (CI 95\%) } & \multirow{3}{*}{ P-Value } \\
\hline & & \multicolumn{2}{|c|}{ Tidak Patuh } & \multicolumn{2}{|c|}{ Patuh } & & & & \\
\hline & & $\mathbf{N}$ & $\%$ & $\mathbf{N}$ & $\%$ & $\mathbf{N}$ & $\%$ & & \\
\hline \multirow[t]{3}{*}{1.} & Pengawas Minum Oba & (PN & & & & & & & \\
\hline & Tidak ada pengawasan & 21 & 35,5 & 38 & 64,4 & 59 & 100 & & \\
\hline & Ada pengawasan & 2 & 2,90 & 67 & 97,1 & 69 & 100 & $18,5(4,1-83,3)$ & 0,000 \\
\hline \multirow[t]{3}{*}{2.} & Dukungan Intrumenta & & & & & & & & \\
\hline & Tidak ada dukungan & 14 & 25,9 & 40 & 74 & 54 & 100 & & \\
\hline & Ada dukungan & 9 & 12,6 & 64 & 87,8 & 74 & 100 & $2,5(1,0-6,3)$ & 0,050 \\
\hline \multirow[t]{3}{*}{3.} & Dukungan Informasi & & & & & & & & \\
\hline & Tidak ada dukungan & 18 & 30 & 42 & 70 & 60 & 100 & & \\
\hline & Ada dukungan & 5 & 7,3 & 63 & 92,6 & 68 & 100 & $5,4(1,8-15,6)$ & 0,002 \\
\hline
\end{tabular}


Journal of Pharmaceutical and Health Research

Vol 2, No 3, Oktober 2021, pp. 60-66

ISSN 2721-0715 (media online)

DOI 10.47065/jharma.v2i3.983

\begin{tabular}{|c|c|c|c|c|c|c|c|c|c|}
\hline \multirow{2}{*}{4.} & Dukungan Penilaian & & & & & & & & \\
\hline & Tidak ada dukungan & 11 & 19,6 & 45 & 80,3 & 56 & 100 & & \\
\hline \multirow{4}{*}{5.} & Ada dukungan & 12 & 16,6 & 60 & 83,3 & 72 & 100 & $1,2(0,4-3,0)$ & 0,664 \\
\hline & Dukungan Emosional & & & & & & & & \\
\hline & Tidak ada dukungan & 13 & 28,2 & 33 & 71,7 & 46 & 100 & & \\
\hline & Ada dukungan & 10 & 12,2 & 72 & 87,8 & 82 & 100 & $2,8(1,1-7,1)$ & 0,027 \\
\hline \multirow[t]{3}{*}{6.} & Dukungan Spritual & & & & & & & & \\
\hline & Tidak ada dukungan & 6 & 12,7 & 41 & 87,2 & 47 & 100 & & \\
\hline & Ada dukungan & 17 & 20,9 & 64 & 79 & 81 & 100 & $0,55(0,2-1,5)$ & 0,247 \\
\hline \multirow[t]{3}{*}{7.} & Dukungan Finansial & & & & & & & & \\
\hline & Tidak ada dukungan & 6 & 9,5 & 57 & 90,4 & 63 & 100 & & \\
\hline & Ada dukungan & 17 & 26,1 & 48 & 73,8 & 65 & 100 & $0,22(0,1-0,6)$ & 0,018 \\
\hline
\end{tabular}

Analisis multivariat mengetahui faktor yang paling berpengaruh dengan kepatuhan minum obat anti tuberculosis paru (OAT) pada pasien tuberculosis paru di Kota Banda Aceh. Secara ringkas hubungan antara peran PMO dan dukungan finansial dengan kepatuhan minum obat anti tuberculosis paru (OAT) di Kota Banda Aceh adalah sebagai berikut:

Tabel 3. Analisis Multivariat

\begin{tabular}{clccc}
\hline No. & \multicolumn{1}{c}{ Variabel } & Odds Ratio & 95\% CI & P. Value \\
\hline 1. & Ada Penawasan Minum Obat (PMO) & 17,6 & $3,8-80,5$ & 0,000 \\
2. & Tidak Ada Dukungan Finansial & 0,32 & $0,10-0,97$ & 0,044
\end{tabular}

\subsection{Hubungan Peran PMO dengan Kepatuhan Minum Obat Pasien TB Paru}

Berdasarkan hasil penelitian menunjukkan bahwa proporsi responden yang mendapatkan pengawasan PMO sebesar $53.9 \%$. Sedangkan responden yang tidak mendapatkan pengawasan PMO sebesar $46 \%$. Ada hubungan peran PMO dengan kepatuhan minum obat anti tuberculosis paru (OAT) di Kota Banda Aceh dengan P-Value 0.000, dimana responden yang patuh minum obat yang mendapatkan mengawasan PMO sebersar 97.10\% hampir satu kali lebih besar dibandingkan dengan responden yang tidak mendapatkan mengawasan PMO sebersar 64.4\%. Sedangkan proporsi responden yang tidak patuh minum obat mendapatkan mengawas PMO sebesar $2.9 \%$ satu kali lebih kecil di bandingkan dengan responden yang tidak mendapatkan mengawas PMO sebesar 3.5\%.

Hasil penelitian ini sejalan dengan penelitian yang dilakukan oleh Ambari \& Prinda (2016) diperoleh hasil bahwa adanya faktor PMO dengan kepatuhan minum obat tuberculosis paru di Puskesmas Sempor 1 Kebumen dengan nilai PValeu 0,004 < 0,05. Selanjutnya hasil penelitian Puri (2010) tentang Hubungan Peran PMO dengan kepatuhan minum obat pada penderita TB paru di Puskesmas Kedungwini II Kabupaten Pekalongan menunjukkan bahwa ada hubungan yang kuat antara peran PMO dengan kepatuhan minum obat pada pasien TB paru.

Peneliti berpendapat bahwa peran PMO mempunyai andil besar dalam meningkatkan kepatuhan pengobatan yaitu dengan adanya dorongan dan pengawasan kepada penderita dalam minum obat, karena dengan adanya PMO yang dekat dengan penderita, pasien yang mempunyai peran PMO baik minum obat, begitu pula sebaliknya semakin kurang peran PMO maka pasien semakin tidak patuh dalam minum obat. Hal ini didukung oleh Manuhara (2012) dukungan sosial, dalam hal ini yang dimaksud adalah keluarga dapat membantu meningkatkan ketataatan pasien.

\subsection{Hubungan Dukungan Instrumental dengan Kepatuhan Minum Obat Pasien TB Paru}

Berdasarkan hasil penelitian menunjukkan bahwa proporsi responden yang ada dukungan intrumental sebesar $57.8 \%$. Sedangkan responden yang tidak ada dukungan intrumental sebesar $42.1 \%$. Hasil penelitian menunjukkan bahwa ada hubungan dukungan intrumental terhadap kepatuhan minum obat pasien tuberculosis paru di Kota Banda Aceh dengan P-Value 0.050, dimana responden dengan patuh minum obat dan mendaptakan dukungan intrumental sebersar $87.8 \%$ hampir satu kali lebih besar dibandingkan dengan responden yang tidak ada dukungan intrumental sebesar $74 \%$, sedangkan proporsi responden yang tidak patuh minum obat ada dukungan intrumental sebesar $12.1 \%$ satu kali lebih kecil di bandingkan dengan responden yang tidak ada dukungan intrumental sebesar $25.9 \%$.

Hasil penelitian ini sejalan dengan hasil penelitian Fitria \& Febriani (2017) yang berjudul hubungan dukungan keluarga dengan kepatuhan minum obat pada penderita tuberkulosis di wilayah kerja Puskesmas Gading Rejo Tahun 2017 mendapatkan hasil ada hubungan antara dukungan instrumental dengan kepatuhan minum obat P-value $=0,07$, hal ini kemungkinan karena jarak atau akses pelayanan kesehatan yang mudah dijangkau, sehingga keluarga dapat mengantarkan pasien setiap ingin berobat ke Puskesmas.

Menurut pendapat peneliti dukungan instrumental diperlukan pasien untuk mendapatkan sarana dalam memenuhi kebutuhannya, keluarga merupakan sumber pertolongan praktis dan konkrit bagi anggota keluarga yang lain. Asumsi masyarakat belakangan ini tentang pemenuhan dukungan instrumental dapat terpenuhi tergantung faktor penghasilan atau status ekonomi keluarga, jika penghasilan yang didapatkan keluarga rendah maka sulit bagi anggota keluarga untuk memberikan dukungan yang diperlukan pasien untuk mendapatkan pengobatan optimal. Namun, dengan sistem pengobatan TB Paru yang saat ini dilakukan secara gratis, maka paradigma dukungan instrumental dapat berubah yaitu berupa kesiapan keluarga dalam ikut mengantarkan pasien TB paru menggunakan kendaraan yang dimiliki untuk 


\title{
Journal of Pharmaceutical and Health Research
}

\author{
Vol 2, No 3, Oktober 2021, pp. 60-66
}

ISSN 2721-0715 (media online)

DOI 10.47065/jharma.v2i3.983

mendapatkan pengobatan penyakit TB itu sendiri di Puskesmas terdekat. Dalam hal ini, sebaiknya dibentuk suatu kelompok atau ormas peduli penyakit TB Paru disuatu desa, sehingga semua keluhan yang dialami oleh keluarga penderita TB dapat ditampung dan diakomodir oleh organisasi tersebut. Hal ini didukung oleh teori Manuhara (2012) dukungan instumental adalah dukungan berupa bantuan dalam bentuk nyata atau dukungan material. Dukungan ini dalam menyediaan benda dan layanan untuk memecahkan masalah praktis.

\subsection{Hubungan dukungan Informasi dengan Kepatuhan Minum Obat Pasien TB Paru}

Berdasarkan hasil penelitian menunjukkan bahwa proporsi responden yang ada dukungan informasi sebesar $56.2 \%$. Sedangkan responden yang tidak ada dukungan informasi sebesar $43.7 \%$. Hasil penelitian menunjukkan bahwa ada hubungan dukungan informasi terhadap kepatuhan minum obat pasien tuberculosis paru di Kota Banda Aceh dengan PValue 0.027 , dimana responden dengan patuh minum obat dan mendapatkan dukungan informasi sebersar $92.6 \%$, hampir satu kali lebih besar dibandingkan dengan responden yang tidak ada dukungan informasi sebesar 70\%. Sedangkan proporsi responden yang tidak patuh minum obat ada dukungan informasi sebesar $7.3 \%$, hampir empat kali lebih kecil di bandingkan dengan responden yang tidak ada dukungan informasi sebesar $30 \%$.

Hasil penelitian ini berbeda dengan hasil penelitian Septia \& Sabrian (2014) yang berjudul hubungan dukungan keluarga dengan kepatuhan minum obat pada pasien tuberkulosis (TBC) di Wilayah Kerja Puskesmas Pamulang Kota Tangerang Selatan Tahun 2014 yang menyatakan tidak ada hubungan dukungan informasi dengan kepatuhan minum obat pada pasien tuberkulosis di wilayah kerja Puskesmas Pamulang dengan P-value $=0,764$. Hal ini dikarenakan tempat penelitian yang di lakukan di kecamatan, sedangkan penelitian yang di lakukan oleh peneliti dilakukan didaerah perkotann, sehingga masyarakat lebih mudah untuk mendapatkan informasi dan pengetahuan tentang penyakit TB paru.

Menurut pendapat peneliti dukungan nasihat, arahan, serta saran membuat pasien merasa mampu dan mantap dalam mengambil keputusan dalam patuh terhadap pengobatan. Bentuk informasi ini dapat menolong individu untuk mengenali dan mengatasi masalah dengan lebih mudah dengan memberikan sugesti dan informasi yang dapat digunakan untuk mengungkapkan suatu masalah. Dukungan informasional juga memberikan penguatan atas perilaku pasien yang sesuai dengan harapan. Maka sebaiknya disuatu desa ditetapkan beberapa kader yang melibatkan keluarga dari masingmasing penderita penyakit TB, sehingga segala informasi yang berhubungan dengan penyakit dan pengobatan TB dapat diterima oleh orang yang tepat. Hal ini didukung oleh teori Douse dalam Manuhara (2012) dukungan informasional berupa pemberian informasi yang dibutuhkan oleh individu. Dukungan ini terdiri atas pemberian informasi atau pengajaran suatu keahlian yang dapat memberi solusi pada suatu masalah sert appraisal support yaitu pemberian informasi yang dapat membentu individu dalam mengevaluasi performance pribadi. Dukungan ini berupa pemberian informasi, nasehat dan bimbingan.

\subsection{Hubungan Dukungan Penilaian dengan Kepatuhan Minum Obat Pasien TB Paru}

Berdasarkan hasil penelitian menunjukan bahwa proporsi responden yang ada dukungan Penilaian sebesar 56.2\%. Sedangkan responden yang tidak ada dukungan Penilaian sebesar $43.7 \%$, hasil penelitian menunjukkan bahwa tidak ada hubungan dukungan Penilaian terhadap kepatuhan minum obat pasien tuberculosis paru di Kota Banda Aceh dengan Pvalue 00.664, dimana responden dengan patuh minum obat dan mendaptakan dukungan Penilaian sebersar $83.3 \%$, hampir satu kali lebih besar dibandingkan dengan responden yang tidak ada dukungan Penilaian sebesar 80.3\%, sedangkan proporsi responden yang tidak patuh minum obat ada dukungan Penilaian sebesar 16.6\%, satu kali lebih kecil di bandingkan dengan responden yang tidak ada dukungan Penilaian sebesar $19.6 \%$.

Hasil penelitian ini berbeda dengan hasil penelitian Fitria \& Febriani (2017) yang berjudul Hubungan dukungan keluarga dengan kepatuhan minum obat pada pasien Tuberkulosis (TBC) di wilayah kerja Puskesmas Pamulang Kota Tangerang Selatan Tahun 2016 yang mendapatkan hasil tidak ada hubungan ukungan keluarga dengan kepatuhan minum obat Tb Paru P-Value $=0.003$. Hasil penelitian ini berbeda dikarenakan karakteristik lokasi penelitian adalah kecamatan dan penelitian yang peneliti lakukan berlokasi di kabupaten. Sehingga kemungkinan terdapatnya adanya pola pikir yang berbeda antara masyarakat di kecamatan dan didaerah kabupaten.

Menurut pendapat peneliti dukungan penilaian timbul karena keluarga sudah menghargai usaha yang telah dilakukan pasien dalam menjaga kesehatannya, keluarga sudah memberikan contoh yang baik untuk pasien dan memberikan kritik yang bersifat membangun sehingga pasien tergerak untuk meningkatkan kesehatannya. Ketika tindakan seseorang mendapatkan pujian atau dorongan positif dari orang lain, maka orang tersebut cenderung akan mengulangi tindakan yang sama. Seperti halnya pada pasien Tb Paru, dimana pada saat mereka sudah menerapkan sikap patuh terhadap minum obat, maka keluarga sebaiknya memberikan pujian atau penghargaan kepada pasien, sehingga pasien merasa senang dan tidak sia-sia dengan usaha yang mereka lakukan. Hal ini didukung teori Fitria \& Febriani (2017) dukungan penilaian dapat ditingkatkan dengan mengkomunikasikan kepada pasien bahwa ia bernilai dan diterima meskipun tidak sempurna.

\subsection{Hubungan Dukungan Emosional dengan Kepatuhan Minum Obat Pasien TB Paru}

Berdasarkan hasil penelitian menunjukan bahwa proporsi responden yang ada dukungan emosional sebesar $62 \%$ sedangkan responden yang tidak ada dukungan emosional sebesar 39.9\% hasil penelitian menunjukkan bahwa ada hubungan dukungan emosional dengan kepatuhan minum obat anti tuberculosis paru (OAT) di Kota Banda Aceh dengan 


\title{
Journal of Pharmaceutical and Health Research
}

\author{
Vol 2, No 3, Oktober 2021, pp. 60-66
}

ISSN 2721-0715 (media online)

DOI 10.47065/jharma.v2i3.983

p-value 0.27 , dimana responden dengan patuh minum obat dan mendaptakan dukungan emosional sebersar $87.8 \%$ hampir satu kali lebih kecil dibandingkan dengan responden yang tidak ada dukungan emosional 71.7\%. Sedangkan proporsi responden yang tidak patuh minum obat ada dukungan emosional sebesar $12.2 \%$ hampir tiga kali lebih kecil di bandingkan dengan responden yang tidak ada dukungan emosional sebesar $28.2 \%$.

Penelitian ini berbeda dikarenakan karakteristik lokasi penelitian Fitria \& Febriani (2017) yang berjudul hubungan dukungan keluarga dengan kepatuhan minum obat pada penderita Tuberkulosis diwilayah kerja Puskesmas Gading Rejo Tahun 2017 yang mendapatkan hasil tidak ada hubungan dukungan emosional terhadap kepatuhan minum obat dengan P Value 0.085. Hasil penelitian ini berbeda dikarnakan penelitian yang lakukan berlokasi di kecamatan, sedangkan penelitian yang dilakukan oleh peneliti di perkotaan sehingga menyebabkan bentuk dukungan keluarga lebih besar dibandingkan di lokasi kecamatan yang keluarganya sebagian besar lebih mengerti cara mengontrol emosionalnya, sehingga perhatian keluarga kepada penderita TB Paru terpenuhi.

Menurut pendapat peneliti perhatian, rasa kasih sayang dan kepedulian, menjaga keadaan emosi pasien, memberikan semangat, kehangatan membuat pasien merasa bahwa ia dihargai, dicintai dan orang lain dalam keluarganya bersedia memberi perhatian dan kasih sayang. Hal ini akan membuat pasien TB paru tidak merasa diasingkan karena penyakitnya, sehingga akan menimbulkan semangat untuk sembuh dengan cara patuh meminum obat. Maka diharapkan bagi keluarga agar mengikuti pelatihan-pelatihan yang dilaksanakan oleh petugas kesehatan terkait dengan pengetahuan dan bimbingan pengobatan TB. Sehingga keluarga dapat memahami keadaan emosi yang dialami oleh penderita. Hal ini di dukung oleh teori Fitria \& Febriani (2017) dukungan emosional adalah dukungan yang melibatkan dari ekspresi dari empati, kepedulian dan perhatian kepada orang lain.

\subsection{Hubungan Dukungan Spritual dengan Kepatuhan Minum Obat Pasien TB Paru}

Berdasarkan hasil penelitian menunjukan bahwa proporsi responden yang ada dukungan spritual sebesar $63.2 \%$ sedangkan responden yang tidak ada dukungan spritual sebesar 36.7\%, hasil penelitian menunjukkan bahwa tidak ada hubungan dukungan spritual dengan kepatuhan minum obat anti tuberculosis paru (OAT) di Kota Banda Aceh dengan P-value 0.247, dimana responden dengan patuh minum obat dan mendapatkan dukungan spritual sebersar $87.80 \%$ hampir satu kali lebih besar di bandingkan dengan responden yang tidak ada dukungan spritual $71.7 \%$. Sedangkan proporsi responden yang tidak patuh minum obat ada dukungan spritual sebesar 12.2\%, hampir tiga kali lebih kecil di bandingkan dengan responden yang tidak ada dukungan spritual sebesar $28.2 \%$.

Hasil penelitian ini sama dengan hasil penelitian yang dilakukan oleh Septia \& Sabrian (2014) berjudul Hubungan dukungan peran PMO dan keluarga dengan kepatuhan minum obat pada pasien Tuberkulosis (TBC) di Wilayah Kerja Puskesmas Sempor 1 Kebumen Tahun 2017 yang mendapatkan hasil tidak ada hubungan ukungan keluarga dengan kepatuhan minum obat Tb Paru P-value $=0.041$. Hasil penelitian ini berbeda dikarnakan penelitian yang lakukan berlokasi di kecamatan dan jumlah sampelnya sedikit. Sedangkan penelitian yang dilakukan oleh peneliti ruang lingkupnya luas dan sampel nya lebih banyak sehingga menyebabkan banyak pendapat.

Menurut pendapat peneliti perhatian, rasa kasih sayang dan kepedulian, menjaga keadaan spritual pasien, memberikan keyakinan dalam berhubungan dengan yang maha kuasa dan maha pencipta, hal ini akan membuat pasien TB paru tidak merasa putus asa karena penyakitnya, sehingga akan menimbulkan keyakinan kepada allah untuk sembuh dengan cara berusaha tetap patuh meminum obat. Maka diharapkan bagi keluarga agar mengikuti pelatihan-pelatihan yang dilaksanakan oleh petugas kesehatan terkait dengan pengetahuan dan bimbingan pengobatan TB. Sehingga keluarga dapat memahami keadaan spritual yang dialami oleh penderita. Hal ini di dukung oleh teori Suprehatin (2011) Spritual merupakan suatu yang dipercayai oleh seseorang dalam hubungannya dengan kekuatan yang lebih tinggi (tuhan), yang menimbulkan suatu kebutuhan serta kecintaanya terhadap adanya tuhan dan permohonan atas segala kesalahan yang pernah diperbuat.

\subsection{Hubungan Dukunga Finansial dengan Kepatuhan Minum Obat Pasien TB Paru}

Berdasarkan hasil penelitian menunjukkan bahwa proporsi responden yang ada dukungan finansial sebesar $50.7 \%$ sedangkan responden yang tidak ada dukungan finansial sebesar $49.2 \%$, hasil penelitian menunjukkan bahwa ada hubungan dukungan finansial dengan kepatuhan minum obat anti tuberculosis paru (OAT) di Kota Banda Aceh dengan P-value 0.018, dimana responden dengan patuh minum obat ada dukungan finansial sebesar $79 \%$ hampir satu kali lebih besar dibandingkan dengan responden yang tidak ada dukungan finansial sebesar $87.2 \%$, sedangkan proporsi responden yang tidak patuh minum obat ada dukungan finansial sebesar 20.9\% hampir satu kali lebih besar di bandingkan dengan responden yang tidak ada dukungan finansial sebesar $12.7 \%$.

Hasil penelitian ini berbeda dengan hasil penelitian yang di lakukan oleh Septia \& Sabrian (2014) berjudul Hubungan dukungan keluarga dengan kepatuhan minum obat pada pasien Tuberkulosis (TBC) di RSUD dr. Saiful Anwar Malang Tahun 2014 mendapatkan hasil tidak ada hubungan antara dukungan finansial dengan kepatuhan minum obat $\mathrm{P}$-Value $=0,087$. Hal ini kemungkinan karena lokasi penelitian di tingkat kecamatan sedangkaan penelitan yang peneliti lakukan perkotaan, sehingga kemungkinan ada perbedaan tingkat ekonomi antara masyarakat di kecamatan dan daerah perkotaan.

Menurut pendapat peneliti memberikan dukungan finansial pada proses penyembuhan penyakit, penderita TB akan memberikan respon dan sikap yang positif untuk menjalan program TB dan minum obat secara teratur demi kesembuhan penyakitnya, dengan minum obat secara rutin penderita TB paru akan terhindar dari resiko resistensi yaitu gagal menjalan 


\title{
Journal of Pharmaceutical and Health Research
}

\author{
Vol 2, No 3, Oktober 2021, pp. 60-66
}

ISSN 2721-0715 (media online)

DOI 10.47065/jharma.v2i3.983

pengobatan dan akan kembali berobat dari awal pengobatan, sehingga akan membuat jangka waktu pengobatan lebih lama dan dengan terapi pengobatan awal, selain resiko penularan kepada keluarga atau orang terdekat yang sering ditemui penderita. Hal ini didukung oleh teori Manuhara (2012) dukungan finansial merupakan penyediaan materi berupa biaya atau fasilitas yang dapat memberikan pertolongan langsung kepada seseorang yang membutuhkan baik dalam keluarga maupun orang lain, bentuk dukungan ini dapat mengurangi kecemasan karna individu dapat langsung memecahkan masalahnya yang berhubungan pembiayaan.

\subsection{Regresi Antara PMO terhadap Kepatuhan Minum Obat Pasien TB Paru}

Berdasarkan hasil analisis menujukkan bahwa $O R=17.69$ dengan 95\% C1 3.88-80.57 antara variabel PMO dengan kepatuhan minum obat, artinya PMO yang mengawasi mempunyai kecendrungan 17.69 kali pasien patuh minum obat di bandingkan dengan yang tidak ada Pengawasan PMO. Hasil penelitiaan ini sependapat dengan yang ditemukan oleh Puri (2010) dengan $O R=14.40$ dengan 95\% C1 1.55-5.75, artinya PMO yang mengawasi mempunyai kecendrungan 14.40 kali pasien patuh minum obat di bandingkan dengan yang tidak ada Pengawasan PMO.

\subsection{Regresi Dukungan Finansial terhadap Kepatuhan Minum Obat Pasien TB Paru di Kota Banda Aceh}

Berdasarkan hasil analisis menujukkan bahwa Odds Ratio dukungan finansial sebesar 0.32, karena Odds Ratio kurang dari 1, maka hasil interpretasinya yaitu pasien yang tidak ada dukungan finansial memiliki kecendrungan 3.1 kali patuh minum obat di bandingkan dengan pasien yang ada dukungan finansial. Hasil penelitian ini berbeda dengan yang ditemukan oleh (Yuniar I., 2017) dengan $O R=2.26$ dengan 95\% C1 2.9-60,1 artinya PMO yang mengawasi mempunyai kecendrungan 2.26 kali pasien patuh minum obat di bandingkan dengan yang tidak ada dukungan finansial.

\section{KESIMPULAN}

Berdasarkan hasil penelitian dan pembahasan mengenai Hubungan Peran PMO dan Dukungan Keluarga dengan Kepatuhan Minum Obat Anti Tuberculosis (OAT) Pasien Tuberculosis Paru di Wilayah Kerja Dinas Kesehatan Kota Banda Aceh maka dapat di simpulkan bahwa ada hubungan antara pengawas minum obat (OR: 18.51: P-Value 0,000), dukungan Informasi (OR: 5.4:P-Value 0,002), dukungan emosional (OR: 2.8: P-Value 0,0027), dan dukungan finansial dengan kepatuhan minum obat di Kota Banda Aceh (OR: 0.2: P-Value 0,018). Serta Tidak ada hubungan antara dukungan instrumental (OR: 2.5: P-Value 0,050), dukungan penilaian (OR: 1.2: P-Value 0,664), dan tidak ada hubungan antara dukungan spitual dengan kepatuhan minum obat di Kota Banda Aceh (OR: 0.5: P-Value 0,247).

\section{DAFTAR PUSTAKA}

Ambari M. \& Prinda K. 2016 Hubungan Antara Dukungan Keluarga dengan Keberfungsian Sosial pada Pasien Skizofrenia Pasca Perawatan di Rumah Sakit: Universitas Diponegoro.

Dinkes, A., Data dan Informasi Profil Kesehatan Indonesia Tahun 2016. Kementrian Kesehatan Republik Indonesia, Pusdatin Kemenkes RI: Jakarta: Pusdatin Kemenkes RI; 2017.

Fitria R. \& Febriani C.A., Hubungan dukungan keluarga dengan kepatuhan minum obat pada pasien Tuberkulosis Paru di Wilayah Kerja Puskesmas Gading Rejo 2015, Jurnal Dunia Kesmas, 2017;5(1):24-31.

Friedman M.M., Keperawatan Keluarga: Teori dan Praktik, Jakarta: EGC, 1998.

Hannan M. \& Hidayat S., Peran Keluarga dalam Perawatan Penderita Tuberkulosis Paru di Kecamatan Gapura Kabupaten Sumenep, Wiraraja Medika, 2013;3(1):16-20.

Kemenkes R.I. 2017. Strategi Nasional Pengendalian TB di Indonesia 2010-2014, Jakarta: Direktorat Jenderal Pengendalian Penyakit Dan Penyehatan Lingkungan.

Manuhara L. 2012. Evaluasi Tingkat Kepatuhan Penggunaan Obat Tuberkulosis Paru Pada Programmed Management on DrugResistant Tuberculosis di Puskesmas Kota Surakarta: Universitas Muhammadiyah Surakarta.

Pradana, W.K., 2018. Hubungan Dukungan keluarga dengan Kepatuhan Minum Obat pada Pasien Tuberculosis paru di Puskesmas Guntung Demak. Fakultas Ilmu Keperawatan UNISSULA.

Puri N.A.2010. Hubungan Kinerja Pengawas Minum Obat (PMO) dengan Kesembuhan Pasien TB Paru Kasus Baru Strategi DOTS: Universitas Sebelas Maret.

Septia A. \& Sabrian F., 2014. Hubungan Dukungan Keluarga Dengan Kepatuhan Minum Obat Pada Penderita TB Paru, Jurnal Online Mahasiswa Program Studi Ilmu Keperawatan Universitas Riau, 1(2):1-10.

Sulis G., Roggi A., Matteelli A. \& Raviglione M.C. 2014 Tuberculosis: Epidemiology and Control, Mediterranean Journal Of Hematology and Infectious Diseases, 6(1).

Suprehatin N. 2011 Hubungan Antara Pengetahuan dan Sikap Orang Tua dengan Perilaku Dalam Pengawasan Minum Obat pada Penderita Tuberkulosis Paru Anak di Balai Besar Kesehatan Paru Masyarakat (BBKPM) Surakarta: Universitas Muhammadiyah Surakarta.

WH0. Global Tuberculosis Report . 2017.World Health Organization 